Наташа П. Кљајић

ОШ „Бранко Радичевић“

Бољевци - Прогар
UDC: $371.3:: 811.163 .41]: 004.5$

DOI: $10.18485 / d h .2015 .2 . c h 4$

\title{
УПОТРЕБА МОБИЛНИХ ТЕЛЕФОНА У НАСТАВИ СРПСКОГ ЈЕЗИКА И КЊИЖЕВНОСТИ
}

\begin{abstract}
Сажетак
У овом раду бавићемо се могућностима употребе тзв. „паметних" мобилних телефона у настави Српског језика и књижевности. Мобилни телефон као свеприсутно средство комуникације од „ометача” све више постаје „пријатељ” наставном процесу. Дозволивши ученицима приступ бежичном интернету и наставно сврховиту употребу мобилних телефона на часовима у условима рада у истуреном одељењу, надоместили смо недостатак наставних средстава, али и ангажовали ученике да ресурсе дигиталне хуманистике искористе у ефикаснијем и данашњем „све-на-клик-детету” примереном режиму наставног поступања. Тиме су испоштовани захтеви интерактивне наставе, корелације са другим наставном садржајима, а учешће демонстративног метода, групног и индивидуалног рада као и стваралачких активности је знатно појачан у односу на тзв. класичан приступ настави. У раду ћемо дати неколико примера из властите основношколске и средњошколске праксе који су се показали као веома успешни, а сматрамо их методички утемељеним и применљивим у наставној пракси.
\end{abstract}

Кључне речи: мобилни телефони, обавезна и изборна лектира, српски језик, настава, претраживање, корелације, интермедијалност, демонстративни метод, иновације, електронска књига.

\section{1. Увод}

Почетна мотивација за писање овог рада лежи у једној педагошкој грешци коју смо починили пре више од две године, несвесни моћи коју мали паметни телефони имају над данашњом "све-на-клик" генерацијом ученика. Вођени школским прописима који забрањују употребу мобилног телефона на часу, опоменули смо 
једну ученицу зато што није умножила песме из корпуса изборне лектире, а притом током часа интензивно користи мобилни телефон. Испоставило се да су све песме ту, пред ученицом, у pdf формату, у меморији паметног телефона. Мобилни телефон, то проказано средство ометања, преписивања, снимања узнемирујућих снимака којима се угрожава интегритет наставника, показало се као раширено, економично и доступно наставно средство. Време је било да „променимо парадигму” и сами набавимо андроид.

Употреба рачунара у процесима учења није нова и неистражена тема, пошто се мултимедијалност садржаја и информатичка писменост ученика истичу као императив у наставном процесу. Међутим, уз мултимедијалне кабинете и паметне табле, за сада доступне релативно малом броју школа ${ }^{1}$, један мањи број кабинета Српског језика поседује по један рачунар, који најчешће подразумева фронтални начин рада и углавном се ограничава на демонстративну употребу. ${ }^{2} \mathrm{C}$ друге стране, већина ученика поседује паметне мобилне телефоне и уз све забране које пред њих стављамо, користе их интензивно, претежно несврховито. Уколико већ не можемо да победимо парадигму „екранске културе”, мобилни телефон који у себи садржи приступ интернету, камеру, фото-апарат, снимач звука и 4-8 GB меморије можемо уважити као корисно демонстративно средство, али и испомоћ у активном учењу и стваралачким активностима у настави Српског језика.

1 Ова наставна средства углавном се налазе у кабинетима Информатике и рачунарства, те најчешће нису доступна осталим наставницима. Постоје и специјализовани кабинети за интерактивно учење осталих предмета (Физика, Енглески језик), али се у праки показало да „презасићеност” интерактивним садржајем доводи до губитка интересовања ученика за овај вид рада, као и да „кружни“ распоред, најпогоднији за информатичке кабинете, бива фактор ометања приликом часова обраде или утврђивања, јер се ученици недовољно фокусирају на рад наставника или задужење које им је дато. Све то доводи и до помањкања дисциплине и неретко, уништавања школске имовине.

2 У учионичкој настави, присутној у већем броју средњих школа, наставник би био у ситуацији да преноси свој лап-топ из учионице у учионицу. У ОШ „Бранко Радичевић” У Прогару, издвојеном одељењу подручне школе у Бољевцима, свака учионица поседује рачунар који се, ради безбедности, чува у металним касетама. Свака употреба стога захтева склапање рачунара на почетку и на крају часа, што одузима извесно време, али и доводидо могућности оштећења уређаја. 
Дозволивши ученицима приступ бежичном интернету и наставно сврховиту употребу мобилних телефона на часовима у условима рада у истуреном одељењу, надоместили смо недостатак наставних средстава, али и ангажовали ученике да ресурсе дигиталне хуманистике искористе у ефикаснијем и данашњем „све-на-клик-детету” примереном режиму наставног поступања. Тиме су испоштовани захтеви интерактивне наставе, корелације са другим наставном садржајима, а учешће демонстративног метода, групног и индивидуалног рада као и стваралачких активности је знатно појачан у односу на тзв. класичан приступ настави.

\section{2. Примена}

Први напредак као наставник видели смо у могућности да обимну педагошку документацију која обухвата рад на четири програма Српског језика и два програма Грађанског васпитања, сведемо на далеко прихватљивију, прегледнију електронску форму. Средивши на лап топу електронску форму планова, програма, припрема и осталих образаца, што је у школској администрацији почев од 2014/2015. озваничено као вид економичности, пренели смо их у меморију мобилног телефона.Озваничивши властиту употребу мобилних телефона у наставне сврхе, више нисмо имали аргумената да ученике опомињемо због држања истих на видљивом месту током часа. У договору са колегама у предметној настави, проследили смо ученицима и шифру за бежични интернет у школи, што се показало као потребно јер нису сви ученици имали могућности за плаћање месечних пакета, или су они били релативно скромни.

Претрага и креирање сазнања била би два основна и најприменљивија правца примене мобилних телефона у настави, односно употреба већ постојећих елемената дигиталне хуманистике те креирање и додавање нових као вид ученичког рада.

Замена за звучне читанке присутна је аудио-записима на сајту Youtube. Наставник може ученицима пустити неки од видео-записа (који се услед мале резолуције телефона) слушају као аудио-записи. 
То могу бити казивања самих песника, интерпретације познатих глумаца или компоноване мелодије по тексту песника:

- Стеван Раичковић: „Небо” (читање аутора) https://www. youtube.com/watch?v=UMcsZ6JKUGg

- Десанка Максимовић чита своју поезију, https://www.youtube. com/watch?v=GBa6YSHLp-Q

- Сергеј Јесењин: „Писмо мајци” - интерпретације Радета Шербеџије (https://www.youtube.com/watch?v=JnbkiC4vOn0) и Ивана Босиљчића (https://www.youtube.com/results?search_query=pismo+m ajci+ivan+bosiljcic) ${ }^{3}$

- Десанка Максимовић: „Стрепња” (у интерпретација Хашима Кучук Хокија: https://www.youtube.com/watch?v=7cL9tU98rLo)

- Десанка Максимовић: „Опомена” (интерпретација Зафира Хаџиманова: https://www.youtube.com/watch?v=RpbA-tNRHPA)

- Милош Црњански: „Ламент над Београдом” (читање песника: https://www.youtube.com/watch?v=PXa1EiyHfeo или нумера „Београд спава" бенда Block Out, са деловима поеме коју чита аутор: https:// www.youtube.com/results?search_query=beograd+spava+block+out).

Као и при употреби стандардне звучне читанке, сматрамо да би уз звучну илустрацију, наставник требало и сам једанпут да прочита ученицима текст из читанке. Тако можемо вршити паралелу између интерпретативног и изражајног читања песме, као и прозног и компонованог облика књижевног дела.

Постављање неколико аудио-записа прозних и драмских књижевнихдела показало сетакође корисним унастави књижевнности. Радио-драма „Капетан Џон Пиплфокс ради се најчешће у виду репрезентативног одломка из читанке у 5. разреду основне школе.Дата је и могућност интегралног читања овог дела у оквиру корпуса „изборне лектире"; током 2010. године појавило се и издање за лектирско читање у издању ЗУНС-а", али у недостатку књига по школским би-

3 Уколико се настава реализује у одељењима која уче Руски језик, ученицима је могуће пустити ову песму и у оригиналу (https://www.youtube.com/watch?v=TTPHLg6Da3k, https://www.youtube.com/watch?v=DBw8X6XAwrY, а код већине издавача у читанкама, песма је упоредо дата и на српском и на руском језику, па је могуће успоставити ванпредметну корелацију

4 Ово издање смо приредили у сарадњи са Драганм Хамовићем и илустратором Миланом Поповићем) 
блиотекама, запис друге верзије радио-драме ${ }^{5}$ из 1974. године, са Љубом Тадићем у главној улози, доступна је на линку https://www. youtube.com/watch?v=CljLu_Wz-mc. Слично је и са радио-драмом „Ноћ и магла“ Данила Киша, са Гораном Султановићем у улози Андреаса Сама која може бити од користи при обради истоимене тв-драме (https://www.youtube.com/watch?v=zNiutcK6ZpU) Основну потешкоћу при обради поменутогдрамског текста јесте обрада у осмом разреду, пре целовитог читања збирке приповедака из збирке „Рани јади” Данила Киша, смештене у први разред средње школе, уз позивање на обрађене појединачне приче у претходним разредима („Дечак и пас", „Вереници”, „Ливада, у јесен”), као и комплексност разумевања појма „варљивости сећања” који се ученицима у овом узрасту може учинити исувише апстрактним. Слушање овог одломка омогућава успоставља ванпредметну корелацију са наставом историје (Други светски рат, Југославија након Другог светског рата), уочавање елемената радиофоније, али и интегралног доживљаја дела, који остаје поприлично блед ако се окренемо само одломку. ${ }^{6}$ Сличан ефекат можемо постићи и слушањем радио-драме „Избирачица” Косте Трифковића, доступне на линку: https://www.youtube.com/watch?v=03NWwSOowc I\&index=23\&list=PLx8Bex5PaX_YUjtiwXEXEXHC7RAEP2uYH, која истина, бива популарна и ради сценски извођена, али се драматизацијом одломка недовољно поентира расплет драме, односно кажњавање уображене удаваче Малчике удајом за „најслабију партију”.

Сродне радио-драмама биле би и звучне књиге, у интегралном или прерађеном облику. Уколико је реч о преради, пожељно је да се успостави компарација између оригиналног и прерађеног текста. Навешћемо неколико доступних: аудио-књига које се у целости или у одломцима:

Антоан де Сент Егзипери: „Мали принц”(https://www.youtube. com/watch?v=PdILMwq24hM)

Петар Петровић Његош: „Горски вијенац” (у интерпретацији Данила Лазовића: https://www.youtube.com/watch?v=L3qBNB2guW8)

5 Прва верзија ове радио-драме из 1954. године нажалост није сачувана.

6 Сматрамо оптималним да се ова наставна јединица реализује током марта или априла јер се у то време реализују садржаји из наставе историје. 
Народна бајка: „Златна јабука и девет пауница” (1. део: https:// www.youtube.com/watch?v=uh2UvIDmjjo, 2. део: ttps://www.youtube. com/watch?v=i97wYmfk7pw)

Иво Андрић: „Изабрани текстови“ („Аска и вук”, https://www. youtube.com/watch? $v=$ uma65S21E54\&index=32\&list $=P L x 8 B$ ex5P aX_YUjtiwXEXEXHC7RAEP2uYH, „Кула”, https://www.youtube.com/ watch?v=T-_Y1Ac50Dg, „У завади са светом”, https://www.youtube.

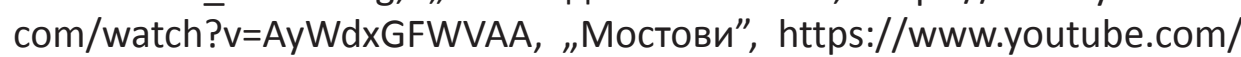
watch?v=e6SgpcKrICw, ).

Употреба звучних записа може да буде делотворна у настави језичке културе, у области неговању правилног усменог изражавања. Рецимо, наставна јединица Ортоепија обично се реализује читањем правилног / неправилног изговора појединих гласова (ч, ћ, p) на основу задатих примера из уџбеника. Међутим, можемо, уколико имамо могућности, уснимити говорнике који мешају ч и ћ (поједини говори источнохерцеговачког дијалекта), са алтернативом читања по норми. Можемо снимити неког од говорника из нашег непосредног окружења, који ће изговорити нестандардни облик говора, а потом ми, или чак и тај говорник чита текст у ијекавском изговору без мечања ч и ћ. Слично томе, можемо ишчитати текст у говор типичом за град Београд и околину (отворено е, губитак постакценатских дужина у генитиву множине женског рода и облима првог и другог лица множине презента). Ученицима из Ваљева или Љига важећа акценатско-ортоепска норма није непозната, али ученицима из Београда облици са очуваним дужинама нису део свакодневне разговорне комуникације, али морају бити део норме. С друге стране, у настави дијалеката у 8. разреду ученицима можемо презентовати записе говора појединих дијалекта са Јутјуба ${ }^{7}$, са задатком да ученици и сами, током посета појединим крајевима Србије усниме чланове породице/пријатеље/познанике који говоре у изворном дијалекту.

7 Најпрепознатљивији су примери из популарних филмова и серија: „Зона Замфирова” за призренско-тимочки, „Село гори, а баба се чешља за косовско-ресавски, „Луд, збуњен, нормалан” за источнохерцеговачки, „Горчило” за зетско-јужносанџачки, „Синђелићи” за шумадијско-војвођански. Одломци се могу слушати преко телефона на часу, са препознавањем дијалеката, или наставник може на свом Фејсбук налогу окачити ученицима аудио/видео записе. 
Током седмог разреда ученици се упознају с техником израде интервјуа, и није непознато да је звучни/видео запис далеко ефектнији од исписивања питања и одговора у свеске. Наставник даје ученицима да у аудио или видео формату сниме интервју. Питања могу бити припремљена (за дужи интервју) или осмишљена у ходу (краћи интервју, анкета). У својој пракси имали смо два ученика која су освојила награду на државном првенству у кајаку. Два ученика из одељења имала су задатак да са победницима направе видеоинтервју у кајак-клубу, где ће промовисати поменути спорт, клуб и своје успехе. Интервју је сниман у рукавцу крај реке Саве, као и у складишту чамацаи у сали за вежбање на ергонометрима. Ученици су представили изглед једног типичног тренинга, карактеристике вожње двојца без кормилара, упознали нас са својим тренером и описали атмосферу на такмичењу. У аудио-запису могу се интервјуисати наставници, знамените личности које посећују школу (као испомоћ за касније штампано или електронске издања школских новина.

Опис такође погодују видео-запису. Рецимо, на тему „Јесење боје” ученица је снимила изглед Бојчинске шуме у јесен, са акцентом на променама у природи које је усмено коментарисала. На тему „Мој љубимац“" две ученице петог разреда заједно су прошетале са својим куцама и представиле их кроз опис њихових особина, активности и неких смешних ситуација, а на тему „Једна необична животиња” једна ученица је снимила и описала своју кобилу Тару, необичну по дугим шишкама, а друга је у Бојчинској шуми снимила легло аутохтоне расе свиња мангулица и описала на сликовит и духовит начин ове збиља необичне животиње. Видео-запис може бити и занимљив као део домаћег задатка „Путујем, бележим” (у форми репортаже). На школској екскурзији или путовањима ученици могу снимити видеоклипове које могу пустити (у том случају потребно је пренети запис у рачунар) и усмено, на основу видео-записа у позадини представити знаменитости које су обишли. Током рада у Гимназији у Младеновцу, задали смо овај домаћи задатак ученицима трећег разреда који су снимили кадрове са екскурзије у Бечу и Будимпешти, са кадровима Шенбруна, бечке Опере, забавног парка Пратер, Сент Андреје, Ланчаног моста и Будимске тврђаве. У то време, једна група ученика 
путовала је на ученичку размену у Италију, па су на тај начин представили своје путешествије бродом преко Јадрана, Бар и Бари, као и знаменитости које су обишли у јужној Италији.

Разуме се, велики простор у настави представља употреба дигиталне фотографије на мобилном телефону. Низ наставних јединица инспирисан је просторно-временским одредницама које наставник или ученици могу усликати и доцније приказати. Ако је реч о једној слици, наставник или ученик може прошетати по одељењу (рецимо, слика манастира Манасије $\rightarrow$ Васко Попа: „Манасија”, фреска Симониде у Сопоћанима $\rightarrow$ Милан Ракић: „Симонида“) ${ }^{8}$, али ако има више слика, пожељно је да ученици ипак пребаце садржај на рачунар.

У седмом разреду обрађује се есејистичко-путописни текст „Потера за пејзажима“ Пеђе Милосављевића.С обзиром да смо са својих приватних путовања, усликали мобилним телефоном локације које се наводе у тексту (Колубара, Вишеград, Сарајево, Требишњица, Неретва, Дубровник, остаци старе железничке трасе воза „ћира”), искористили смо их да их покажемо ученицима током обраде текста, ссортиране по редоследу како су представљени у тексту. Ученици тог одељења углавном нису обишли ове локације па им је било више него драгоцено да виде фотографије места које Пеђа Милосављевић описује. С друге стране, ученици истог одељења су у шестом разреду посетили манастир „Манасију” па су током седмог разреда неколико слика уснимљених мобилним телефоном приказали. У седмом разреду обрађује се и текст „Кањош Мацедоновић“, лоциран у Венецији.

8 Појединачне фотографије или репродукције могу бити усликане или преузете с интернета. Наставник током самог часа може неком ученику дати задатак да пронађе фреску Симониде за истоимену Ракићеву песму или Вермерову слику “Девојка с бисерном минђушом” као илустрацију за песму „Бисерне очи” која се обрађује у седмом разреду, а у пракси се показала као прилично херметична за тумачење у узрасту седмог разреда основне школе. Додатни проблем представља право одређеног издавача на употребу одређене репродукције приликом издавања уџбеника (најчешће зУнС-а у односу на приватне издаваче), чиме ученици бивају лишени репродукције фреске Симониде или репродукција „Кнежеве вечере”, „Косовке девојке” или фреске „Свети ратници” у манастиру Манасија). Репродукција је замењена најчешће илустрацијом, а сведоци смо (не)успеллости истих да замене саму репродукцију као најсврховитије решење при употреби демонстратиног метода и успостављање ванпредметних корелација. Стога, претраживање садржаја који нам недостају у читанкама итекако бива погодно и потребно током самог часа. 
Један ученик је са породичног путовања у Венецију донео неколико слика као пример. С обзиром да радимо у Прогару, једном типичном селу у Срему, приликом обраде романа „Поп Ћира и поп Спира”, задали смо ученицима да мобилним телефонима у свом селу и суседним Бољевцима усликају куће, баште, дворишта и цркву који би личили на топосе из Сремчевог романа. У сопственим баштама, старим кућама у селу и сеоској цркви, забележили су слике које би наликовале на амбијент поменутог дела, укључујући и елементе екстеријера (стари сат, диван, соба са перјаним јастуцима у етно кући, фијакер), чак су се две девојчице маскирале у Јулу и Меланију (војвођанска ношња са фолклора : дамска хаљина). При обради текста „Лето лепог белца" Вилијама Саројана у шестом разреду ученица је у оближњој коњичкој школи сликала белог коња у падоку, у неколико кадрова, са два дечака која су јахала коња.

Такође, водећи се предавањем проф. др Вељка Брборића „Јавни записи и натписи” представљеном на Зимском републичком семинару 2013. године, у коме су усликани јавни записи и натписи са правописним грешкама. Наставник може сам усликати јавне записе и натписе са типичним грешкама у писању или куцању па их демонстровати ученицима на часовима правописа, али може дати и задатак ученицима да усниме поједине натписе у свом окружењу и потом објасне где уочавају огрешење о норму и како погрешан натпис и сами да исправе.

Даћемо пример два натписа које су ученици сами уснимили и објашњавали као део домаћег задатка из правописа: ${ }^{9}$

1. „Продајем кућу”

На усликаном огласу ученици су уочили следеће грешке:

- Куцачка грешка у наслову (родајем ум. продајем), рећу воћњак (вочњак), спојено писање назива улице и броја куће (Каменова52);

-Употреба цртице уместо црте у писању теза;

-Писање властитих именица великим словом уместо малим (плац, воћњак)

9 Овом проблематиком детаљније се бавио колега Саша Чорболоковић из ОШ „3. октобар" у Бору који је у току школске 2014/2015. организовао фото-конкурс за ученике „Ма ко је бре неписмен?”. 
- Изостанак тачке и запете на крају сваке тезе;

- Два узвичника уместо тачке на крају последње тезе.

2. Циркус „Медрано”

Ученици уочавају падежну грешку: уместо у акузативу, називи занимања која тражи циркус дати су у номинативу (аутолимар-лакирер ум. аутолимара-лакирера, вариоц цирада ум. вариоца цирада), тј. није испоштована конгруенција глагола и именица.

\section{3. Назив лека}

Ученици у основној школи уче да се називи производа пишу малим словом, између осталог и називи лекова. С друге стране, на кутијама лекова домаћих фармацеутских кућа примећију да се лекови пишу великим словом, што представља огрешење о норму.

Фотографије јавних натписа и записа са правописним грешкама препознатљиве суи веома често се јављају на форумима, сајтовима, правописним групама на друштвеним мрежама. Разуме се, фотографије нуде и правила и типичне грешке. Неке од тих фотографија наставник или ученик може сместити у меморију мобилног телефона, па на примерима објашњавати норму/огрешење о норму:

1. Лого за „плазма” кекс на чашици за воду:

Норма је испоштована, тј. назив производа пише се малим словом. 2. Писање назива школе (писање вишечланих назива установа):

Ученици уочавају да се други и трећи члан вишечланог назива пишу великим словом,односно да је у овом јавном натпису у административном обрасцу дошло до грубог огрешења о правописну норму ( XIV Београдска Гимназија ум. XIV београдска гимназија )која захтева писање малим словом.

У настави историје језика и лексикологије слике приказане на мобилном телефону могу бити драгоцене, наставник им може на телефону приказати неколико интересантних фотографија:

1. графеме српске ћирилице - значење графема: ${ }^{10}$ (7. и 8. разред ОШ, 1. разред средње школе:

10 Доступно на: https://www.facebook.com/photo.php?fbid=10150326017922833\&set=o 151611781596379\&type=3\&theater<23.06.2015> 
2. историзми (8. разред ОШ, 3. разред средње школе): ${ }^{11}$

Наставни план и програм Српког језика у основној школи подразумева и читање тзв. изборне лектире, односно, оних књижевних дела у допунском избору које наставник према предложеном списку или сопственој процени уноси у корпус дела која се обрађују у обиму од три до пет дела годишње. ${ }^{12}$ У читанкама и радним свескама могу се наћи краћи текстови у целости, али кад је реч о романима или збиркама приповедне прозе, они су заступљени са репрезентативним одломцима. Ако је реч о делу које је својевремено било на списку обавезне лектире или се често издавало, из корпуса књижевне класике, онда није неизводљиво оћи до довољног броја примерака (Џек Лондон: „Глас дивљине”, Бранко Ћопић: „Доживљаји Николетине Бурсаћа") , мада ћемо неретко доћи и до апсурдне ситуације да су ови наслови због некоришћења у јавним и неким школским библиотекама доживели неславну судбину фонда за отпис у процесу ревизије. Међутим, новији наслови у школским библиотекама набављени су у малом броју примерака или их уопште нема. Поред неколико примерака који се размењују у оквиру одељења, наставник може упутити ученике на линк електронске књиге са кога ће ученици преузети дело у електронском формату и читати на мобилним телефонима:

11 Доступно на: https://www.facebook.com/photo.php?fbid=961671400538962\&set=gm.8 73606206059536\&type=1\&theater<23.06.2015>

12 Када је по реформисаном Наставном плану и програму традиционална и у много чему вештачка подела на школску и домаћу лектиру замењена поделом на обавезну и изборну, сам концепт отворио је могућност да наставник у договору са ученицима, уважавајући постојеће предлоге и литерарне квалитете одабраних дела, „прошири“ устаљени и генерацијски утврђени канон књижевноуметничких дела оним остварењима из књижевне класике или савремене продукције који би савременим читачима били ближи, приступачнији, допадљивији. Криза читања са којом се наставник свакодневно суочава, посебно упливом медијских „све-наклик" садржаја који дисперзивну ученичку пажњу тешко одржава на једном месту, условљава промену парадигме, захтева садржаје који неће изневерити вредност васпитних, образовних и функционалних циљева, али ни занемарити читалачке потребе и навике ученика у савременом наставном окружењу. Изборна лектира нуди могућност „замене“, уколико наставник уочи да дело више нема адекватну рецепцију код ученика, односно ако читалачки чин поред сазнајног нема и стваралачкорекреативни потенцијал, могуће је да уведе неко ново дело, прилагођавајући се могућностима, жељама и интересовањима ученика. 
Џ. Селинџер: „Ловац у житу” (http://www.tenis-as.com/downloadeknjige/selindzer-lovac-u-zitu.pdf) - изборна лектира за 8. разред ОШ;

Ефраим Кишон: „Код куће је најгоре” (http://os-tenja.skole.hr/ upload/os-tenja/images/static3/1345/attachment/EPHRAIM_KISHONknjiga.do...) - изборна лектира за 6. разред ОШ.

У средњој школи (претежно наставни план гимназије) , на списку лектире налази се низ аутора српске и светске књижевности чија се дела (претежно поезија), не могу наћи у читанкама. Постоје приручници „Лектира 1-4" Љиљане Николић ${ }^{13}$, али у пракси они се најчешће не користе ${ }^{14}$, посебно у унутрашњости. Наставник може ученицима давати да копирају одређене песме из поменутих приручника или неких других извора, али се показало да је далеко ефикасније да учениици направе самосталан избор песама или да сами нађу задате песме, служећи се штампаним или електронским изворима. Претрага се може вршити и на самом часу, ученици имају задатак да пронађу једну песму и да је прочитају, а затим наставник са ученицима може дискутовати о садржини песме. Наравно, могуће је да ученици и код куће пронађу песме, сачувају их у меморију телефона и потом читају на часу. Даћемо линкове који би могли бити од користи:

Матија Бећковић: „Вера Павладољска”(http://www.yurope.com/ people/nena/Stihovi/Matija_Beckovic/Vera_Pavladoljska.html), програм 2. разреда друштвено-језичког и општег смера гимназије;

Рајнер Марија Рилке: „Поезија” (http://www.prelepapoezija. com/tag/rajner-marija-rilke-pesme/) - програм 3. разреда гимназије;

Гијом Аполинер: „Поезија” (http://www.jovicaletic.com/cms/?page_ id=659, http://www.kcb.org.rs/Programi/Pesmanadan/Pesmanadannajava/ tabid/1095/AnnID/1135/language/sr-Latn-CS/Default.aspx); - програм 3. разреда гимназије.

Растко Петровић: „Поезија” (http://www.rastko.rs/knjizevnost/umetnicka/ poezija/rpetrovic-otkrovenja.html) - програм 3. разреда гимназије друштвено-језичког и општег смера;

13 У издању ИП „Ваша књига”, више издања.

14 Приручници нису одобрени од Министарства просвете Републике Србије као наставно средство, реч је о помоћним приручницима. По статуту већине школа забрањена је продаја свих наставних средстава ученицима која нису уврштена у годишњи план и одобрена за употребу. 
Еме Сезар: „Избор из поезије” („Тужаљка кише” - http:// magicnature-ankica.blogspot.com/p/poezija_10.html) - програм 4. разреда друштвено-језичког смера гимназије;

ЛеополдСедар Сенгор: „Избор из поезије” („Црна жена” - http:// www.artnit.net/pero/item/574-leopold-sedar-sengor-crna-\%C5\%BEena. html) - програм 4. разреда гимназије.

У програму лектире за 4. разред гимназије налази се и Пекићева приповетка „Човек који је јео смрт” из збирке „Нови Јерусалим”, која се у школским библиотекама тешко проналази, број примерака у јавним библиотекама најчешће бива скроман и недовољан за школске потребе, али је доступна на Scribd-y. ${ }^{15}$ на линку: На истом сајту можемо пронаћи и pdf издање драме „Развојни Пут Боре Шнајдера” Александра Поповића ${ }^{16}$, док на сајту Стеријиног позорја проналазимо текст драме „Балкански шпијун” Душана Ковачевића ${ }^{17}$. Премда је током 2015. године ИП „Лагуна” реиздала роман „Кад су цветале тикве" Драгослава Михаиловића који је такође био заступљен у скромном броју примерака у школским библиотекама, а има изузетну рецепцију међу средњошколцима, и овај наслов може се читати на мобилном телефону и сачувати у меморији. ${ }^{18}$

\section{Мобилни телефон - пријатељ наставе (закључак)}

Побројани аспекти употребе мобилног телефона у настави представљају окосницу могућности које наставници Српског језика и књижевности у основној и средњој школи могу истражити заједно са својим ученицима. Мобилни телефон вше није прогнан из видо-

15 Доступно на: http://www.scribd.com/doc/61418950/Borislav-Peki\%C4\%87-\%C4\%8Covekkoji-je-jeo-smrt-1793

16 Доступно на: (http://www.scribd.com/doc/48288641/\%D0\%A0\%D0\%90\%D0\%97\%D0\% 92\%D0\%9E\% D0\%88\%D0\%9D\%D0\%98-\%D0\%9F\%D0\%A3\%D0\%A2-\%D0\%91\%D0\%9E\%D0 \%A0\%D0\%95-\%D0\%A8\%D0\%9D\%D0\%90\%D0\%88\%D0\%94\%D0\%95\%D0\%A0\%D0\%90\%D0\%90\%D0\%BB\%D0\%B5\%D0\%BA\%D1\%81\%D0\%B0\%D0\%BD\%D0\%B4\%D0\%B0 \%D1\%80-\%D0\%9F\%D0\%BE\%D0\%BF\%D0\%BE\%D0\%B2\%D0\%B8\%D1\%9B Доступно на: http://www.pozorje.org.rs/scena/drame/DKovacevic-BalkanskiSpijun.pdf. Доступно на: https://tamoiovde.files.wordpress.com/2012/01/kad-su-cvetale-tikve.pdf. 
круга наставе, он се заједно са свеском, уџбеничким комплетом или књигом лектире налази на клупи, покрај ученика. Нараво, употреба мобилног телефона је дозирана и контролисана од наставника, односно наставно сврховита.

Процес учења савременог детета можда најбоље илуструје следећа слика: ${ }^{19}$

Духовит приказ телефона као ометајућег фактора у процесу учења може се схватити и другачије, као помоћ у учењу, неопходно средство. Затворена књига на последњој сличици неће онда бити одбачена књига, већ прочитана књига, књигачије је градиво савладамо.

Можемо ли и ми одрасли негирати да употребом мобилних телефона свакодневно учимо? Можемо ли као наставници негирати да у припреми реализације наставе не користимо изворе дигиталне хуманистике на паметним мобилним телефонима? Зашто онда кажњавати ученике ако их користе на часу? Привикнимо их да их користе у корист свог сазнања, као испомоћ у учењу. Резултати неће изостати.

\section{Литература}

\section{Штампана литература}

Вучковић, Живојин, Тодоров, Нада. Култура читања у времену Интернета, Инђија: Народна библиотека „Ђорђе Натошевић”. 2010.

Маринковић, Симеон. Методика креативне наставе српског језика и књижевности. - 3. изд. Београд: Креативни центар, 2003.

МркАљ, Зона. Појам корелације у методици наставе // Методички видици. Часопис за методику филолошких и других друштвено-хуманистичких предмета. - Нови Сад : Филозофски факултет. 2010.

Николић, Милија. Методика наставе српског језика и књижевности. - 3. допуњено изд. Београд: ЗУНС, 1999.

ПАвловић, Миодраг. Припремање ученика и наставника за тумачење књижевног дела. Београд, ЗУНС. 2008.

СтАнолчић, Живојин, Поповић Љ.убомир. Граматика српскога језика, Београд: ЗУНС. 2012.

19 Доступно на: https://www.facebook.com/photo.php?fbid=10206787513108715\&set=0. 151611781596379\&type=3\&theater 


\section{Електронска литература}

Вугделија, Наталија и Савић, Ана (2013). Мобилни интернет у образовању. <infoteh.etf.unssa.rs.ba/zbornik/2013/radovi/RSS-4/RSS-4-11.pdf>14. 07. 2015.

КојчИЋ, 3. (2012). УПОТРЕБА МОБИЛнИХ тЕХНОЛОГИЈА У НАСТАВИ. <http://www. academia.edu/4953986/Upotreba_mobilnih_tehnologija_u_nastavi> 14. 07. 2015.

МИНИЋ С. И ДР. (2011) УПОТРЕБА И ЗНАЧАJ WLAN И МОБИЛНИХ ТЕХНОЛОГИЈА У НАСТАВИ. <HTTP://WWW.FTN.KG.AC.RS/KONFERENCIJE/TIO6/RADOVI/4)\%20ELEKTRONSKO\%20 UCENJE/PDF/404\%20SINISA\%20MINIC.PDF>14. 07. 2015.

Ferriter, William (2010). Digitally Speaking / Cell Phones as Teaching Tools. < http:// www.ascd.org/publications/educational-leadership/oct10/vol68/num02/CellPhones-as-Teaching-Tools.aspx>14. 07. 2015.

Norton, Joanna (2014). Teaching tips: how students can use mobiles to learn English.

http://www.britishcouncil.org/blog/teaching-tips-how-students-can-use-mobiles-tolearn-english 15. 07. 2015.

Ormidson, Meg. How to Use Cell Phones as Learning Tools,

< http://www.teachhub.com/how-use-cell-phones-learning-tools>14. 07. 2015. 


\author{
Nataša P. Kljajić \\ Elementary school "Branko Radičević" \\ Boljevci - Progar
}

\title{
THE USE OF MOBILE PHONES IN SERBIAN LANGUAGE TEACHING METHODS
}

\begin{abstract}
Summary
This paper will address the possibilities of use of the so-called "Smart" mobile phones in teaching Serbian language and literature. Mobile phone as a ubiquitous means of communication of the "jammers" is increasingly becoming a "friend" of teaching process. By allowing uor populs to access to wireless Internet and teaching purposeful use of mobile phones in lessons in working conditions in the branch, we have replaced the lack of teaching aids, but also have engaged students to take advantage of humanities digital resources in effective, today's "all-the-click-child" an appropriate regime teaching procedures. Time requirements are satisfied interactive teaching, correlations with other teaching facilities, and participation demonstrative methods, group and individual work and creative activity is significantly enhanced in relation to the so-called. classical approach to teaching. In this paper we will give a few examples from our own primary and secondary school practices that have proven to be very successful, and we consider them methodically established and applicable in practice.
\end{abstract}

Key words: mobile phones, Serbian language classes, search, correlation, intermedijalnost, demonstrative methods, forms of work, innovation, e-books. 